\title{
Anteseden leader endorsement: Perspektif teori identitas sosial
}

\author{
Yoga Aji Nugraha, Samian, \& Corina D. Riantoputra* \\ Fakultas Psikologi, Universitas Indonesia, Depok, Jawa Barat
}

\begin{abstract}
Abstrak
Salah satu kunci dari efektivitas kepemimpinan adalah bagaimana seorang pemimpin diterima dan didukung oleh bawahannya (leader endorsement). Penelitian ini bertujuan untuk mengidentifikasi faktor-faktor yang memengaruhi dukungan bawahan terhadap pemimpin berdasarkan teori identitas sosial. Artikel ini memiliki hipotesis bahwa prototipikalitas pemimpin (leader prototypicality) dan personal bases of power dari pemimpin (expert power dan referent power) memengaruhi dukungan bawahan terhadap pemimpinnya. Menggunakan online surveys kami berhasil mendapatkan partisipan sebanyak 135 karyawan dari berbagai perusahaan swasta di Indonesia. Reliabilitas masing-masing alat ukur yang digunakan berkisar antara 0,80 - 0,90. Hasil analisis menunjukkan bahwa: (1) leader prototypicality tidak signifikan memengaruhi leader endorsement $(\beta=.124 ; \mathrm{p}<.05)$; (2) leaders' expert power $(\beta=$ $.767 ; \mathrm{p}<.01)$ dan leaders' referent power $(\beta=.363 ; \mathrm{p}<.01)$ signifikan memengaruhi leader endorsement. Faktor tersebut mampu memprediksi varian leader endorsement sebesar 78,3\%, $\mathrm{F}(3.94)=56.706, \mathrm{p}<.01$. Temuan penelitian ini dapat memberikan kontribusi terhadap perkembangan teori identitas sosial bahwa pada konteks perusahaan swasta, identitas sosial pemimpin bukan menjadi faktor yang menentukan terbentuknya dukungan terhadap pemimpin.
\end{abstract}

Kata kunci: Identitas sosial, leader endorsement, leader prototipicality, leaders expert power, leaders referent power

\begin{abstract}
One of the keys to leadership effectiveness is how a leader is accepted and supported by his subordinates (leader endorsement). This study aims to identify the factors that influence subordinate support for leaders based on social identity theory. This article hypothesizes that leader prototypicality and leaders' personal bases of power (expert power and referent power) influence leader endorsement. Using online surveys, we managed to get as many as 135 employees from various private companies in Indonesia. The reliability of each measuring instrument used is between 0.80 to 0.90 . The analysis showed that: (1) leader prototypicality did not significantly affect leader endorsement $(\beta=.124 ; p<.05)$; (2) leaders' expert power ( $\beta$ $=.767 ; \mathrm{p}<.01)$ and leaders' referent power $(\beta=.363 ; \mathrm{p}<.01)$ significantly influence the leader endorsement. These variables can predict $78,3 \%$ of leader endorsement variants, $F(3.94)=$ $56.706, \mathrm{p}<.01$. The findings of this study can contribute to the development of social identity theory that in the context of private companies, the social identity of leaders is not a determining factor in leader endorsement.
\end{abstract}

Keywords: social identity, leader endorsement, leader prototipicality, leaders expert power, leaders referent power

\section{Pendahuluan}

Seorang komedian asal Ukraina, Volodymyr Zelensky terpilih menjadi Presiden Ukraina dengan berhasil mengalahkan rivalnya yang merupakan petahana yaitu Presiden Petro Poroshenko, dengan meraih $73 \%$ suara (Kennedy, 2019). Meskipun berlatar belakang komedian dan dinilai maju sebagai calon presiden untuk menantang petahana sebagai suara protes publik, pria 41 tahun tersebut justru mampu memenangi pertarungan politik dan mendapatkan dukungan sebanyak lebih dari 30 juta dari total 45 juta jiwa penduduk di Ukraina (Kennedy, 2019).

Zelensky dianggap mampu menampilkan karakteristik yang sesuai dan dapat mewakili nilai-nilai, perilaku, perasaan, keyakinan (beliefs), dan sikap (attitudes) yang diinginkan penduduk Ukraina, sehingga dapat memenangkan perta-

* Fakutas Psikologi, Universitas Indonesia 
rungan dalam merebut dukungan masyarakat di Ukraina. Hal tersebut dapat terlihat dalam program kampanye politiknya yaitu "ingin membawa orang-orang baik dan profesional ke tampuk kekuasaan untuk mengakhiri korupsi yang terus terjadi pada pemerintahan petahana" dan "sangat ingin mengubah konstelasi politik di Ukraina dari cengkeraman oligarki" (Kennedy, 2019).

Fenomena ini menunjukkan bahwa identitas Zelensky yang semula dianggap minoritas karena berlatar belakang dari dunia komedi dan bukan tipikal individu yang mengerti dunia politik, justru mendapatkan dukungan yang besar dari masyarakat Ukraina karena dianggap merepresentasikan identitas dirinya sebagai rakyat biasa yang ingin mengubah Ukraina menjadi lebih baik. Hal ini juga terjadi seiring menurunnya tingkat kepercayaan rakyat Ukraina terhadap pemerintahan Poroshenko yang terlalu fokus pada platform patriotik, sehingga dianggap berseberangan dengan mayoritas rakyat Ukraina yang kian lelah menghadapi masalah korupsi dan perang proksi dengan Rusia (Kennedy, 2019).

Gambaran fenomena di atas dapat dikaji melalui pendekatan identitas sosial yang menjelaskan bahwa di dalam sebuah proses kepemimpinan, cara pemimpin memandang dirinya dan dapat dipahami oleh orang lain sangat tergantung pada konteks lingkungannya (DeRue \& Ashford, 2010). Kondisi tersebut dapat memberikan informasi bahwa dukungan akan tercipta pada kondisi-kondisi tertentu, ketika pemimpin mampu menampilkan atribut-atribut atau identitas yang sesuai dengan yang dipersepsikan anggotanya (Williams, Pillai, Deptula, Lowe, \& Mccombs, 2018). Sehingga dalam hal ini, peneliti merasa dukungan yang diberikan anggota kelompok terhadap pemimpinnya (leader endorsement) merupakan mekanisme yang sangat fundamental untuk dikaji dalam sebuah proses kepemimpinan (Michener \& Lawler, 1975; van Knippenberg \& Hogg, 2003; Gleibs \& Haslam, 2016; Guo, 2016; Williams dkk., 2018).

Leader endorsement dapat diartikan sebagai dukungan terhadap para pemimpin, yang ditandai dengan ekspresi kepuasan terhadap kinerja seorang pemimpin dalam mengarahkan kelompok, kesediaan untuk bekerjasama dan berkolaborasi dengan pemimpin tersebut dan menerima pengaruh atau arahannya, serta adanya komitmen anggota kelompok terhadap peran pemimpinnya (Michener \& Lawler, 1975; Van Vugt \& De Cremer, 2003). Leader endorsement memiliki peran penting dalam efektivitas kepemimpinan karena dengan leader endorsement para pemimpin dapat membangun dan mempertahankan pengaruh mereka dalam suatu kelompok (Riyadi, Asakarunia, Wijaya, \& Riantoputra, 2019). Dutton, Roberts, dan Bednar (2010) men- jelaskan bahwa identitas kepemimpinan seseorang dapat dilihat dari penilaian evaluatif bawahannya terhadap pemimpin. Apabila evaluasi bawahan terhadap pemimpin menunjukkan penilaian positif, maka endorsement akan diberikan kepada pemimpinnya tersebut.

Studi-studi sebelumnya tentang anteseden leader endorsement dapat diklasifikasikan berdasarkan faktor karakter pemimpin dan juga persepsi dari bawahan (Rast, Gaffney, Hogg, \& Crisp, 2012; Spisak, Grabo, Arvey, \& van Vugt, 2014) dan bentuk dari organisasi (Koivisto \& Rice, 2016). Salah satu faktor yang masih menarik untuk dikaji adalah leader prototypicality. Leader prototypicality didefinisikan sebagai sejauh mana karakteristik pemimpin mewakili karakteristik kelompok atau organisasinya (Hogg, 2001; Pierro, Cicero, Bonaiuto, van Knippenberg, \& Kruglanski, 2005). Menurut teori social identity of leadership, endorsement akan diberikan kepada pemimpin yang memiliki identitas yang sesuai dengan identitas organisasinya. Prototypical leader akan lebih didukung oleh bawahannya dibandingkan non-prototypical leader, karena dianggap telah mewakili identitas, nilai-nilai, perilaku, perasaan, beliefs, attitudes dari sebuah organisasi tersebut (Hogg, 2001; Knippenberg \& Hogg, 2003).

Berdasarkan penelitian yang telah dilakukan sebelumnya, non-prototypical leader sering dikaitkan dengan "glass cliff effect", yang menunjukkan bahwa terdapat kelompok-kelompok tertentu (misalnya wanita) di organisasi yang selalu dihadapkan dengan kritik atau kegagalan secara strategis dalam peran kepemimpinannya, sehingga hal tersebut membuat non-prototypical leader tidak mudah mendapatkan dukungan dari bawahannya (Haslam \& Ryan, 2008). Namun, terdapat temuan penelitian yang menarik terkait hubungan leader prototypicality dan leader endorsement di mana temuan tersebut menjelaskan bahwa tidak semua protoypical leader akan mendapatkan dukungan dari bawahannya. Di sisi lain, non-prototypical leader juga memungkinkan untuk mendapatkan dukungan dari bawahannya dalam kondisi tertentu (Rast dkk., 2012; Rast, Hogg, \& Tomory, 2015).

Hasil penelitian telah mengungkapkan bahwa leader endorsement akan terbentuk ketika seorang pemimpin lebih berorientasi kepada kelompoknya (Graf, Schuh, van Dick, \& van Quaquebeke, 2012). Studi lainnya menjelaskan bahwa dukungan terhadap pemimpin akan terbentuk ketika seorang pemimpin mempunyai strategi-strategi dan metode tertentu yang membuat karyawan merasa nyaman dengan pekerjaannya (Koivisto \& Rice, 2016; Gleibs \& Haslam, 2016). Pemimpin yang akan mendapatkan dukungan adalah pemimpin yang efektif dan mampu membuat bawahan merasa yakin bahwa 
pemimpinnya berhasil dalam memimpin organisasi (Pierro dkk., 2005; van Knippenberg, 2011; Guo, 2016; Gleibs \& Haslam, 2016). Berdasarkan penelitian-penelitian sebelumnya, peneliti menduga bahwa karakteristik pemimpin yang mencerminkan identitas organisasinya, seperti nilainilai, perilaku, perasaan, beliefs, attitudes akan berdampak pada peningkatan leader endorsement.

Beberapa penelitian telah mengeksplorasi kemungkinan adanya kondisi tertentu yang dapat memengaruhi leader endorsement (Graf dkk., 2012; Rast dkk., 2012; Spisak dkk., 2014; Koivisto \& Rice, 2016). Meskipun demikian, ada faktor menarik yang masih perlu dieksplorasi lebih lanjut terkait kemampuan yang dimiliki oleh seorang pemimpin (Chiu, Balkunid, \& Weinberg, 2015). Menurut Chiu dkk., (2015), kemampuan yang dimiliki seorang pemimpin mampu memberi kekuatan sosial yang besar, karena merupakan atribut penting yang dapat membedakan seseorang sebagai pemimpin dan bukan pemimpin. Ketika bawahan memahami bahwa karakteristik unik pemimpin mereka sesuai dengan skema yang sudah ada sebelumnya (misalnya, memiliki kemampuan dan keahlian tertentu dalam berinteraksi dengan bawahannya), seseorang akan lebih cenderung dilihat sebagai pemimpin daripada bukan pemimpin (Epitropaki, Sy, Martin, Tram-quon, \& Topakas, 2013; Geys, 2014).

Faktor lain yang diduga memengaruhi leader endorsement namun masih minim penjelasannya adalah social bases of power (Hinkin \& Schriesheim, 1989). Social base of power dikategorikan menjadi dua, yaitu formal power dan personal power (Robbins \& Judge, 2011). Formal power diartikan sebagai kapasitas atau pengaruh yang dimiliki individu terhadap kelompoknya, yang diperoleh karena posisi sah di organisasi, serta kemampuan individu dalam mengendalikan imbalan dan hukuman (Robbins \& Judge, 2011). Sedangkan personal power dapat diartikan sebagai kapasitas atau pengaruh yang dimiliki individu, karena adanya karakteristik unik yang melekat, misalnya keterampilan dan pengetahuan khusus tertentu dan sifat pribadi individu tersebut seperti karisma dan sebagainya (Robbins \& Judge, 2011).

Pada studi ini kami akan fokus pada personal power, yakni power yang melekat pada individu karena kemampuan atau karakteristik yang dimiliki. Pemilihan fokus ini didasari atas beberapa pertimbangan. Pertama, formal power akan menghasilkan dukungan karena jabatan formal yang dipegang dalam organisasi. Sedangkan personal power yang melekat pada kemampuan dan karakteristik personal pemimpin akan menghasilkan dukungan dari bawahan tanpa melihat jabatan formalnya di organisasi. Kedua, personal power pemimpin yang lebih berperan dalam menentukan efektivitas kepemimpinan di mata bawahannya (Ferris dkk., 2009). Personal power yang terdiri dari expert power dan referent power merupakan atribut yang seharusnya dimiliki oleh pemimpin untuk memengaruhi bawahannya. Dukungan akan cenderung diberikan kepada pemimpin yang memiliki pengaruh tertentu kepada bawahannya (Epitropaki, \& Martin, 2004).

Penelitian terkait social bases of power terutama personal power seorang pemimpin telah banyak dikaitkan dengan pengaruhnya pada efektivitas kepemimpinan, performa kerja, dan kepuasan bawahan pada pemimpinnya (Bachman, Smith, \& Slesinger, 1966; Rahim, 1989; Biong, Nygaard, \& Silkoset, 2010). Selanjutnya efektivitas kepemimpinan dan kepuasan bawahan pada pemimpinnya tersebut juga berhubungan dengan dukungan bawahan untuk pemimpinnya (Platow \& van Knippenberg, 2001; Ullrich, Christ, \& van Dick, 2009). Berdasarkan argumentasi tersebut, kami menduga expert power dan referent power yang dimiliki pemimpin akan dapat membentuk persepsi dukungan bawahan terhadap pemimpinnya (leader endorsement).

Penelitian ini juga dilakukan untuk melihat personal power yang dimiliki pemimpin melalui teori identitas sosial yang diartikan sebagai sebuah proses pengaruh, sehingga hal tersebut mampu membuat keterlibatan dan dukungan dari orang lain dalam mencapai tujuan kolektif, tanpa proses paksaan atas orang lain (van Knippenberg \& Hogg, 2003). Hal ini berkaitan dengan temuan penelitian sebelumnya bahwa terdapat proses-proses tertentu yang membuat seorang pemimpin cenderung lebih didukung dari prototypical leader (Rast dkk., 2012). Teori identitas sosial melihat hal ini sebagai proses kategorisasi diri pemimpin serta dampaknya terhadap hubungan pemimpin dengan bawahannya dalam konteks tertentu. Para pemimpin dapat menggunakan power yang dimilikinya ketika terdapat jarak yang lebar antara pemimpin dan bawahan atau bentuk status tertentu yang tidak setara (misalnya stereotip, diskriminasi antarkelompok, ketidaksukaan sosial) (Haslam \& Ryan, 2008). Sehingga peneliti berharap hasil penelitian ini dapat memperluas penjelasan temuan penelitian sebelumnya.

Penelitian ini bertujuan untuk melihat faktor-faktor yang dapat memengaruhi terbentuknya dukungan bawahan terhadap pemimpinnya (leader endorsement). Meskipun beberapa studi sebelumnya telah mengeksplorasi faktor yang memengaruhi leader endorsement (Koivisto \& Rice, 2016; Rast dkk., 2012; Spisak dkk., 2014), tetapi masih minim penelitian yang menyelidiki 
personal bases of power dan identitas sosial pemimpin terhadap leader endorsement.

Selanjutnya penelitian ini dilakukan untuk melihat gambaran leader endorsement dari perspektif teori identitas sosial dalam konteks di organisasi swasta. Bawahan pada organisasi swasta dianggap memiliki kebebasan yang lebih tinggi dalam mempersepsikan dukungan terhadap pemimpinnya dibandingkan organisasi dengan jarak kekuasaan tinggi seperti organisasi pemerintahan (Hofstede, 2011). Sehingga dalam hal ini, peneliti ingin melihat sejauh mana leader prototypicality mendapatkan dukungan karena perbedaan jenis organisasi dapat memengaruhi sikap dan interaksi yang terjadi antara pemimpin dan bawahannya (Petrick \& Quinn, 2000).

Berdasarkan penjelasan di atas, penelitian ini bertujuan untuk "menganalisis faktor-faktor yang dapat memengaruhi terbentuknya dukungan bawahan terhadap pemimpinnya (leader endorsement), dengan memeriksa variabel leader prototypicality, leaders expert power, dan leaders referent power."

\section{Identitas Sosial: Leader Endorsement}

Konsep leader endorsement memberikan sebuah gagasan tentang harapan bawahan terhadap kepemimpinan yang ideal sehingga mereka bersedia untuk berkolaborasi dan mengikuti arahan pemimpinnya (Van Vugt \& De Cremer, 2003). Leader endorsement dapat diartikan sebagai dukungan bawahan terhadap para pemimpinnya, yang ditandai dengan ekspresi kepuasan terhadap kinerja pemimpin dalam mengarahkan kelompok tersebut, adanya kesediaan bekerjasama dengan pemimpin dan menerima pengaruh/arahannya, serta terciptanya komitmen bawahan terhadap peran yang dilakukan pemimpinnya (Michener \& Lawler, 1975). Leader endorsement dapat pula diartikan sebagai salah satu bentuk dukungan anggota pada pemimpinnya yang mampu memenuhi kebutuhan relasional anggota kelompok dan juga pencapaian beberapa tujuan kelompok tertentu (Van Vugt \& De Cremer, 2003). Sedangkan menurut Graf dkk., (2012), leader endorsement adalah sejauh mana seseorang menerima dan mendukung pemimpin yang dianggap sebagai orang yang tepat untuk memimpin suatu kelompok.

Konsep leader endorsement dapat dikaji dengan teori social identity of leadership, yang mengintegrasikan teori social identity dan teori self categorization (Hogg, 2001). Pendekatan teoritis ini berfokus pada faktor-faktor untuk memberikan dukungan (leader endorsement) dari sudut pandang bawahannya, terutama karena menyangkut masalah identitas yang terkait dengan bawahan dan pemimpin. Pendekatan ini menganggap bahwa keanggotaan kelompok yang menonjol atau penting akan membentuk sikap, perasaan, dan perilaku. Pemimpin dan bawahannya akan mendefinisikan diri mereka tidak hanya dalam hal identitas dan hubungan pribadi, tetapi juga dalam hal identitas sosial, berdasarkan pada arti penting kelompok, keanggotaan seseorang, dan prototipikal dalam kelompok (Hogg, 2001). Berdasarkan penjelasan tersebut, leader endorsement memiliki arti penting dalam efektivitas kepemimpinan karena dengan leader endorsement para pemimpin dapat membangun dan mempertahankan pengaruh mereka dalam suatu kelompok.

\section{Pengaruh Leader Prototypicality terhadap Leader Endorsement}

Kepemimpinan adalah sebuah proses yang berkembang dan tercipta dalam suatu kelompok dan dapat dipengaruhi oleh prototipikalitas (S.A Haslam, Reicher, \& Platow, 2013). "Prototipikalitas" di sini mengacu pada representasi kognitif dari atribut atau fitur, seperti kepercayaan, sikap, perasaan, dan perilaku, yang menjadi ciri suatu kelompok dan membedakannya dari kelompok lain (Hogg, 2001). Representasi ini dapat berbeda antarindividu dari satu lingkungan dengan lingkungan yang lain, dan dari satu budaya dengan budaya yang lain.

Leader prototypicality sendiri didefinisikan sebagai sejauh mana karakteristik pemimpin mewakili karakteristik kelompok atau organisasinya (Hogg, 2001; Pierro dkk., 2005). Sedangkan menurut Rast dkk., (2015), prototypical leader adalah pemimpin yang dianggap dapat membawa serta meningkatkan identity, beliefs, attitudes, feelings, dan juga behavior dari sebuah organisasi yang membedakan organisasi tersebut dengan organisasi lainnya. Berdasarkan beberapa pengertian di atas dapat disimpulkan bahwa leader prototypicality adalah sejauh mana seorang pemimpin dianggap memiliki karakteristik yang mewakili kelompok atau organisasinya di antara organisasi atau kelompok lain yang berbeda.

Pada pembahasan sebelumnya, penelitian terkait hubungan antara leader prototypicality dan leader endorsement masih menjadi penelitian yang menarik untuk dikaji. Berdasarkan teori social identity of leadership, endorsement akan diberikan kepada pemimpin yang memiliki identitas yang sesuai dengan identitas organisasinya. Terdapat kemungkinan besar bahwa prototypical leader akan lebih didukung dibandingkan non-prototypical leader, karena dianggap telah mewakili identitas, nilai-nilai, perilaku, perasaan, beliefs, dan attitudes dari sebuah organisasi (Hogg, 2001; Knippenberg \& Hogg, 2003). 
Untuk memahami lebih baik bagaimana perspektif identitas sosial berpengaruh pada leader prototypicality dan leader endorsement, penting untuk menyadari bahwa keanggotaan kelompok di organisasi akan berdampak pada identitas. Sehingga keanggotaan kelompok adalah sesuatu yang dapat mencerminkan bagaimana individu melihat dirinya sendiri dan orang lain di organisasi. Hal ini merujuk pada organizational identification, yaitu persepsi dan perasaan menyatunya anggota kelompok dengan organisasinya (Mael \& Ashforth, 1992). Individu dengan organizational identification yang tinggi cenderung memiliki keterlibatan yang lebih tinggi dengan kelompok dan pemahaman yang lebih baik tentang karakteristik kelompoknya (Mael \& Ashforth, 1992). Oleh karena itu organizational identification dapat menjadi variabel kontrol pada penelitian ini. Selanjutnya, beberapa penelitian juga telah menghubungkan leader prototypicality dengan kualitas positif seorang pemimpin yang efektif (Knippenberg \& Hogg, 2003; Cicero, Pierro, \& Knippenberg, 2010; van Knippenberg, 2011; Giessner, Knippenberg, \& Ginkel, 2013). Knippenberg dan Hogg (2003) juga menyatakan bahwa efektivitas kepemimpinan berhubungan dengan dukungan dari bawahan (leader endorsement). Berdasarkan argumentasi tersebut, peneliti mengajukan hipotesis penelitian: leader prototypicality berpengaruh positif terhadap leader endorsement.

\section{Pengaruh Personal Power (Leaders' Expert Power dan Leaders' Referent Power) pada Leader Endorsement}

Expert power dan referent power merupakan bagian dari personal power, yang berasal dari karakteristik unik individu. Leaders expert power merupakan kemampuan seorang pemimpin untuk mengelola informasi dan pengetahuan tertentu (Hinkin \& Schriesheim, 1989). Sedangkan menurut Robbins dan Judge (2011), leaders expert power adalah suatu pengaruh yang dimiliki individu sebagai hasil dari keahlian, keterampilan khusus, atau pengetahuan. Expert power biasanya digunakan ketika suatu pekerjaan menjadi lebih terspesialisasi, sehingga dibutuhkan seorang yang ahli untuk mencapai tujuan dari pekerjaan tersebut. Definisi lainnya juga menjelaskan bahwa leaders expert power merupakan sebuah persepsi tentang atribut kepemimpinan seorang yang dilihat berdasarkan pengetahuan dan pengalaman tertentu (Bachman dkk., 1966). Berdasarkan penjelasan di atas, dapat disimpulkan bahwa leaders expert power merupakan sebuah karakteristik unik seorang pemimpin yang berasal dari kemampuannya dalam memengaruhi orang lain dengan pengetahuan, keterampilan khusus dan dari keahlian yang dimiliki.

Studi sebelumnya menemukan hasil bahwa leaders expert power dapat memengaruhi kepuasan kerja bawahan (Rahim, 1989). Penelitian lain menyebutkan bahwa leaders expert power dapat berdampak pada efektivitas dalam memimpin, karena ketika seseorang memiliki kemampuan tertentu yang dibutuhkan organisasi, ia akan secara efektif melakukan tugasnya dengan baik (Haslam dkk., 2013). Selain itu, leaders expert power juga berhubungan dengan kemampuan interpersonal yang berperan untuk membangun hubungan yang baik antara pemimpin dan bawahan kelompoknya (Chiu dkk., 2015). Penelitian terkait expert power banyak membahas pengaruhnya pada efektivitas kepemimpinan, performa dan kinerja, hingga kepuasan bawahan pada pemimpinnya (Bachman dkk., 1966; Rahim, 1989; Biong dkk., 2010). Selanjutnya, efektivitas kepemimpinan dan kepuasan bawahan pada pemimpin tersebut juga akan sangat terkait dengan adanya dukungan bawahan untuk pemimpinnya (leader endorsement) (Pierro dkk., 2005; van Knippenberg, 2011; Gleibs \& Haslam, 2016; Guo, 2016). Berdasarkan pada landasan penelitianpenelitian tersebut, peneliti mengajukan hipotesis kedua: leaders' expert power berpengaruh positif terhadap leader endorsement.

Bentuk lain dari personal power adalah leaders' referent power. Leaders' referent power merupakan kemampuan seorang pemimpin untuk mengelola sebuah perasaan dan penerimaan secara pribadi (Hinkin \& Schriesheim, 1989). Leaders' referent power juga dapat diartikan sebagai sebuah kemampuan yang dapat memengaruhi bawahan karena kharisma, keteladanan, dan kepribadian seorang pemimpin (Robbins \& Judge, 2011). Berdasarkan beberapa definisi tersebut, dapat disimpulkan bahwa leaders' referent power merupakan sebuah karakteristik unik seorang pemimpin yang dapat digunakan untuk memengaruhi orang lain dengan karisma, keteladanan, dan kepribadian, sehingga dapat memimpin sebuah organisasi dengan lebih efektif.

Seperti expert power, beberapa studi telah menghubungkan leaders' referent power dengan kepemimpinan yang efektif (Robbins \& Judge, 2011; Biong dkk., 2010; Haslam dkk., 2013). Kemudian seperti yang telah dijelaskan, efektivitas kepemimpinan akan sangat terkait dengan dukungan bawahan untuk pemimpinnya lleader endorsement) (Pierro dkk., 2005; van Knippenberg, 2011; Guo, 2016; Gleibs \& Haslam, 2016). Berdasarkan argumentasi tersebut, kami mengajukan hipotesis: leaders' referent power berpengaruh positif terhadap leader endorsement. Model hubungan antarvariabel dapat digambarkan sebagai berikut: 
Gambar 1.

Model Penelitian

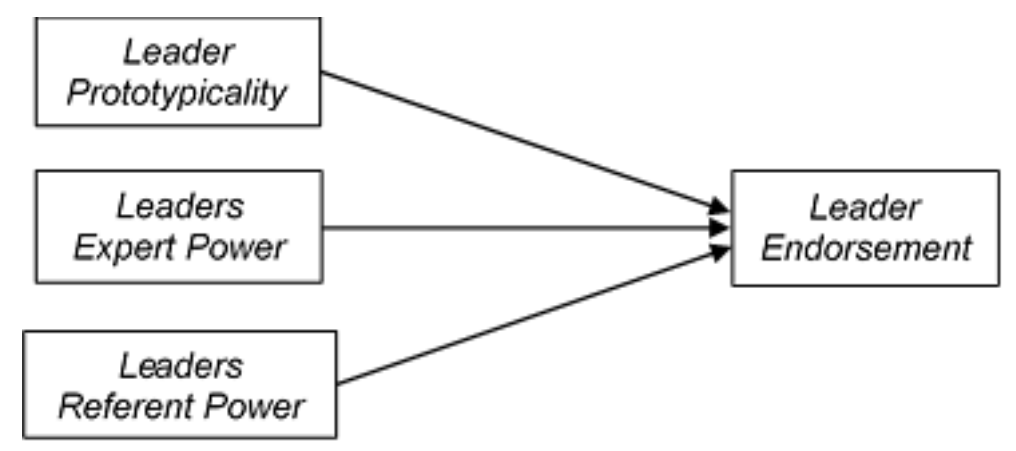

\section{Metode Penelitian}

\section{Partisipan}

Data penelitian ini dikumpulkan dengan menggunakan self report (online survey). Partisipan adalah 135 karyawan yang telah bekerja minimal 1 tahun di berbagai perusahaan swasta pada beberapa provinsi di Indonesia (Jakarta, Jawa Barat, Jawa Tengah, dan Sumatera Selatan). $57,8 \%$ partisipan adalah pria dan sisanya adalah perempuan; rata-rata semua partisipan berusia 25,53 tahun ( $S D=2,99$ ); rata-rata memiliki masa kerja 23,8 bulan $(S D=17,13)$. Pemilihan perusahaan swasta didasarkan pada dua pertimbangan. Pertama, penelitian sebelumnya menunjukkan bahwa jenis organisasi dapat memengaruhi sikap dan interaksi yang terjadi antara pemimpin dan bawahan (Petrick \& Quinn, 2000). Kedua, karyawan pada perusahaan swasta dianggap memiliki kebebasan yang lebih tinggi dalam mempersepsikan dukungan terhadap pemimpinnya dibandingkan tipe-tipe organisasi yang memiliki jarak kekuasaan tinggi seperti organisasi-organisasi pemerintahan (Hofstede, 2011). Teknik sampling menggunakan convenience sampling, yaitu pemilihan berdasarkan kriteria praktis tertentu, seperti aksesibilitas yang mudah, kedekatan geografis, ketersediaan pada waktu tertentu, atau kesediaan untuk berpartisipasi sesuai tujuan penelitian (Ilker, Sulaiman, \& Rukayya, 2016).

\section{Alat Ukur}

Alat ukur yang digunakan pada penelitian ini adalah skala yang terdiri dari 6 point Likert scale ( 1 = sangat tidak sesuai; 6 = sangat sesuai). Alat ukur diadaptasi dengan melakukan back-to-back translation. Peneliti menerjemahkan setiap item ke dalam bahasa Indonesia dengan bantuan expert translator. Selanjutnya tahapan uji coba dilakukan untuk mengetahui tingkat reliabilitas alat ukur. Perhitungan uji reliabilitas menggunakan teknik Cronbach's
Alpha menunjukkan seluruh alat ukur mempunyai reliabilitas konsistensi internal yang baik, dengan rentang koefisien reliabilitas $\alpha$ antara .80 sampai .90 .

Leader endorsement. Penelitian ini menggunakan enam item dari alat ukur Endorsement of a Formal Leaders Scale yang diadaptasi dari Michener dan Lawler (1975), terkait dengan persepsi partisipan tentang dukungannya terhadap pemimpin, Contoh item "I'm satisfied with my leader's use of his/her power in arriving at group decisions" dan "I'm willing to cooperate with my leader" $(\alpha=.93)$.

Leader prototypicality. Penelitian ini menggunakan enam item dari alat ukur perceived leader ingroup prototypicality scale yang diadaptasi dari Platow dan van Knippenberg (2001) terkait persepsi partisipan tentang pemimpin mereka. Contoh item "Overall, I would say that my leader represents the characteristics of (name of company)" $(\alpha=.86)$.

Leaders' expert power. Variabel ini diukur menggunakan lima item dari alat ukur New Power Scale yang diadaptasi dari Hinkin dan Schriesheim (1989) yang terkait dengan persepsi partisipan tentang atribut yang dimiliki pemimpin mereka. Contoh item "My supervisor can give me good technical suggestions" dan "My supervisor can share with me his/her considerable experience and/or training" ( $\alpha=.91)$.

Leaders' referent power. Variabel ini menggunakan lima item dari alat ukur New Power Scale yang diadaptasi dari Hinkin dan Schriesheim (1989) terkait dengan persepsi partisipan tentang atribut yang dimiliki pemimpin mereka. Contoh item "My supervisor can make me feel valued" dan "My supervisor can make me feel like he/she approves of me" $(\alpha=.94)$.

\section{Variabel Kontrol}

Dalam menganalisis dukungan bawahan terhadap pemimpinnya (leader endorsement), peneliti mengontrol variabel demografis seperti 
tingkat pendidikan pemimpin, masa kerja partisipan di institusi dan di unit divisi, dan masa kerja partisipan di bawah pemimpin. Peneliti juga mengontrol Organizational Identification, yaitu persepsi dan perasaan menyatunya anggota dengan organisasi di mana ia berada (Mael \& Ashforth, 1992). Individu dengan organizational identification yang tinggi cenderung memiliki keterlibatan yang lebih tinggi dengan kelompok dan juga pemahaman yang lebih baik tentang bagaimana mendefinisikan karakteristik kelompok mereka (Mael \& Ashforth, 1992). Organizational identification sendiri telah diungkapkan dapat memengaruhi persepsi anggota tentang leader prototypicality (Platow \& van Knippenberg, 2001). Mengontrol organizational identification memungkinkan peneliti untuk mendapatkan data leader prototypicality yang lebih akurat dari partisipan. Organizational identification diukur menggunakan enam item organizational identification scale dari Mael dan Ashforth (1992).

\section{Teknik Analisis}

Setelah data terkumpul, peneliti menyeleksi berdasarkan kelengkapan pengisian dan data demografis partisipan. Tidak terdapat data yang tidak diikutkan dalam proses analisis. Seluruh partisipan mengisi kuesioner secara lengkap. Peneliti menguji hipotesis menggunakan analisis statistik dengan bantuan program IBM SPSS Statistics 22.0. Teknik analisis yang digunakan untuk menguji pengaruh antara leader prototypicality, leaders' expert power, dan leaders' referent power terhadap leader endorsement adalah multiple regression.

\section{Hasil Penelitian}

Hasil analisis korelasi menunjukkan bahwa variabel demografi yang berkorelasi dengan leader endorsement adalah: tingkat pendidikan pemimpin $(r=.178 ; p<.05)$; masa kerja di organisasi $(r=.195 ; p<.05)$; masa kerja di divisi $(r=.261 ; p<.01)$; masa kerja bawahan di bawah pimpinan langsungnya $(r=.186 ; p<.05)$. Variabelvariabel tersebut dikontrol dalam analisis regresi. Namun terdapat variabel agama pemimpin yang tidak berkorelasi dengan leader endorsement ( $\mathrm{r}$ $=$.058). Selanjutnya, Variabel organizational identification behubungan signifikan dengan leader endorsement $(r=.258 ; p<.01)$ sehingga variabel ini juga akan dikontrol dalam analisis regresi. Variabel bebas (independent variable) yang terdiri dari leader prototypicality $(r=.657$; $p<.01)$, leaders' expert power $(r=.824 ; p<.01)$, dan leaders' referent power $(r=.684 ; p<.01)$ juga berhubungan signifikan dengan dengan leader endorsement. Means, standard deviations, dan correlations ditampilkan pada tabel 1.

Hasil analisis regresi dapat dilihat pada tabel 2. Peneliti melakukan uji koefisien regresi untuk mengetahui apakah model regresi dapat digunakan untuk memprediksi variabel dependen atau tidak. Hasilnya terlihat bahwa skor F adalah sebesar $56.706(\mathrm{p}<.01)$, sehingga variabel independen secara bermakna memengaruhi variabel dependen. Selanjutnya variabel leader prototypicality, leader expert power, dan leader referent power mampu memprediksi varian leader endorsement sebesar 78,3\% dalam model regresi, $\mathrm{F}(3.94)=56.706, p<.01$ dengan mengontrol variabel tingkat pendidikan pemimpin, masa kerja di instansi, masa kerja di divisi, masa kerja bawahan di bawah pimpinan langsungnya, serta organizational identification. Leader prototypicality tidak signifikan sebagai prediktor leader endorsement $(\beta=.124 ; p<.05)$ atau dengan kata lain $\mathrm{H} 1$ penelitian ini tidak terbukti, Sedangkan leaders' expert power $(\beta=767 ; p<.01)$ dan leaders' referent power $(\beta=.363 ; p<.01)$ signifikan sebagai prediktor leader endorsement, sehingga $\mathrm{H} 2$ dan $\mathrm{H} 3$ penelitian ini terbukti. Hasil penelitian ini menunjukkan bahwa, dukungan bawahan terhadap pemimpin (leader endorsement) tidak dilihat hanya berdasarkan pada seberapa prototipikal seorang pemimpin di dalam organisasi. Melainkan juga temuan ini menunjukkan bahwa dukungan akan terbentuk ketika pemimpin memiliki pengaruh dan kemampuan seperti leaders' expert power dan leaders' referent power.

\section{Diskusi}

Penelitian ini dilakukan dengan tujuan untuk menganalisis faktor-faktor yang dapat memengaruhi dukungan bawahan terhadap pemimpinnya (leader endorsement) dengan landasan teori identitas sosial (Hogg, 2001). Faktor-faktor yang dianalisis adalah leader prototypicality, leaders' expert power dan leaders' referent power. Hasil dari penelitian ini menunjukkan bahwa faktorfaktor yang signifikan dapat memengaruhi dukungan bawahan terhadap pemimpinnya (leader endorsement) adalah leaders' expert power dan leaders' referent power. Sedangkan leader prototypicality tidak memengaruhi dukungan bawahan terhadap pemimpinnya. Hasil penelitian ini memberikan dua gambaran tentang faktor-faktor yang dapat memengaruhi leader endorsement. 
Tabel 1.

Means, Standard Deviations, and Correlations

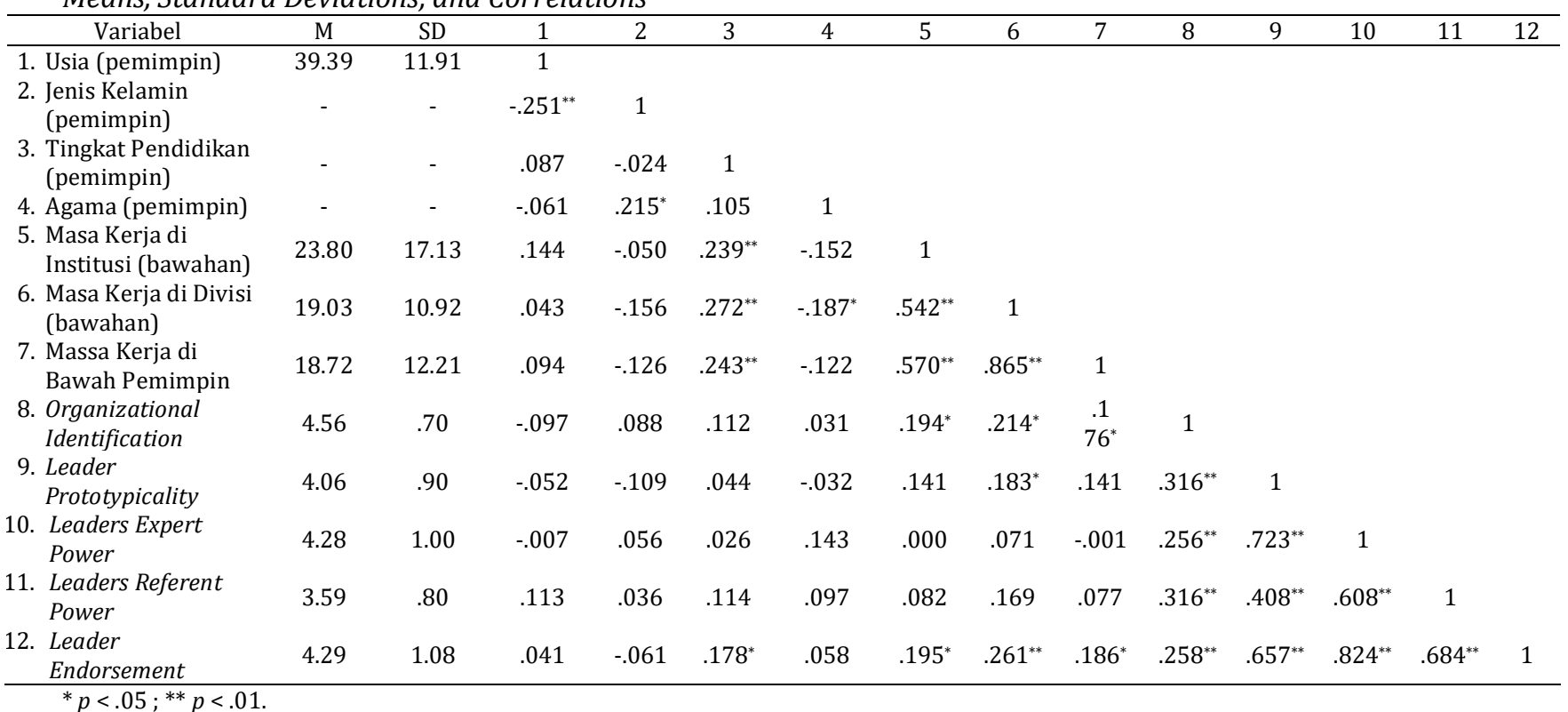

Tabel 2.

Analisis Regresi

\begin{tabular}{lcc}
\hline \multicolumn{1}{c}{ Variabel } & Leader Endorsement & \\
\hline Masa Kerja di Instansi (bawahan) & Step 1 & Step 2 \\
Masa Kerja di Divisi (bawahan) & .025 & .037 \\
Masa Kerja di Bawah Pemimpin & .183 & .040 \\
Tingkat Pendidikan Pemimpin & -.094 & .015 \\
Organizational Identification & .996 & .863 \\
Leader Prototypicality & $.308^{*}$ & -.092 \\
Leaders' Expert Power & - & .124 \\
Leaders' Referent Power & - & $.767^{* *}$ \\
$\mathrm{R}^{2}$ & - & $.363^{* *}$ \\
R adjust. & .129 & .783 \\
$F$ & .096 & .769 \\
df1, df2 & 3.837 & 56.706 \\
\hline
\end{tabular}

Pertama, temuan penelitian menjelaskan bahwa proses terbentuknya dukungan terhadap pemimpin tidak dapat dilihat hanya berdasarkan identitas kepemimpinan yang mencerminkan identitas organisasinya. Prototypical leader tidak selamanya akan lebih didukung dibandingkan non-prototypical leader, seperti yang dijelaskan studi-studi pendahulu (misalnya Dijke \& Cremer, 2010; Hogg, 2001; Knippenberg \& Hogg, 2003; Ullrich dkk., 2009).

Proses terbentuknya dukungan terhadap pemimpin harus dilihat secara resiprokal dan berdasarkan identitas-identitas sosial yang dapat memengaruhi interaksi antara bawahan dan pemimpinnya (DeRue \& Ashford, 2010). Penelitian ini juga telah memasukkan faktor lain sebagai variabel kontrol yang juga memengaruhi dukungan bawahan terhadap leader prototypicality, salah satunya adalah masa kerja.
Leader prototypicality tidak berhubungan dengan leader endorsement diduga karena ratarata masa kerja bawahan yang belum cukup lama di organisasi ( $M=23,80$ bulan) dan divisi ( $M=19,03$ bulan), bahkan belum cukup lama bekerja di bawah pemimpin langsungnya ( $\mathrm{M}=$ 18,72 bulan). Temuan ini diperkuat hasil penelitian sebelumnya bahwa masa kerja memengaruhi organizational identification bawahan (Oktug, 2013). Kondisi partisipan yang masa kerjanya belum terlalu lama memengaruhi persepsi dan identifikasinya dalam mengenal pemimpinnya secara personal. Selain itu, masa kerja yang masih tergolong singkat menyebabkan karyawan belum mengenal dengan baik identitas yang dibangun di dalam organisasi, sehingga mereka bisa mengategorikan pemimpinnya sebagai seorang yang prototypical atau non-prototypical dalam memimpin organisasi tersebut. 
Temuan dalam penelitian ini juga diperkuat dengan hasil penelitian sebelumnya, bahwa prototypical leader tidak selamanya lebih didukung dibandingkan non-prototypical leader (Rast dkk., 2015), karena terdapat faktor-faktor lain yang dapat memengaruhinya. Faktor situasional seperti ketidakpastian diri (self-uncertainty) dapat memengaruhi dukungan bawahan terhadap leader prototypicality (Rast dkk., 2015). Kondisi ini kemungkinan dapat juga dikaitkan dengan rata-rata masa kerja bawahan yang telah digambarkan di atas. Sehingga, ketika bawahan belum memiliki masa kerja yang cukup lama dan belum secara baik mengenal identitas yang dibangun oleh pemimpin di organisasi tersebut, maka kondisi ini dapat membentuk ketidakpastian diri (self-uncertainty) yang pada akhirnya memengaruhi kapasitas kognitif pada bawahan dalam mengidentifikasi pemimpinnya. Kapasitas kognitif ini kemudian akan berkaitan dengan bagaimana cara bawahan mengidentifikasi identitas kepemimpinan yang relevan dengan leader prototypicality secara berbeda-beda berdasarkan motivasi mereka (Rast dkk., 2015).

Kedua, hasil penelitian mengungkapkan bahwa dukungan bawahan terhadap pemimpin (leader endorsement) dipengaruhi oleh personal power yang dimiliki pemimpin, yaitu leaders' expert power dan leaders' referent power. Temuan penelitian ini menggambarkan bahwa pemimpin yang memiliki kemampuan atau keahlian, pengetahuan tertentu dan juga memiliki karisma atau keteladanan akan sangat didukung oleh bawahannya. Hasil ini juga menegaskan bahwa leaders' expert power dan leaders' referent power memang menjadi faktor yang mampu meningkatkan efektivitas kepemimpinan dalam bentuk leader endorsement (Biong dkk., 2010; Haslam dkk., 2013). Sejalan dengan temuan studi-studi sebelumnya tentang leader prototypicality, hasil penelitian ini dapat memberikan gagasan bagi non-prototypical leader untuk tetap dapat mengembangkan identitasnya sebagai seorang pemimpin. Faktorfaktor yang memengaruhi dukungan bawahan terhadap pemimpin (leader endorsement) tidak ditentukan hanya karena pemimpin tersebut prototipikal, tapi lebih ditentukan oleh personal power yang dimiliki pemimpin (leaders' expert power dan leaders' referent power).

Temuan penelitian ini mungkin juga dipengaruhi oleh faktor organisasi. Penelitian sebelumnya menunjukkan bahwa jenis organisasi dapat memengaruhi sikap dan interaksi yang terjadi antara pemimpin dan bawahannya (Petrick \& Quinn, 2000). Penelitian ini dilakukan di organisasi swasta, sehingga karyawan pada perusahaan swasta dianggap memiliki kebebasan yang lebih tinggi dalam persepsi mendukung pemimpinnya. Pada perusahaan swasta, alasan bawahan mendukung pemimpinnya adalah kemampuankemampuan tertentu terkait personal power. Alasan tersebut mungkin akan berbeda pada karyawan di organisasi yang jarak kekuasaannya tinggi seperti organisasi-organisasi pemerintahan. Karyawan pada organisasi yang jarak kekuasaan tinggi kemungkinan akan mendukung pemimpinnya karena formal power atau formal position (Hofstede, 2011).

Selanjutnya, berdasarkan teori social identity dan self categorization, faktor identitas yang terkait dengan bawahan dan pemimpin akan memengaruhi dukungan bawahan atau pekerja terhadap pemimpinnya. Pendekatan ini menganggap bahwa keanggotaan kelompok yang penting atau menonjol akan membentuk sikap, perasaan, dan perilaku. Sekalipun demikian, studi ini menunjukkan bahwa tidak ada korelasi antara persepsi bawahan mengenai agama pemimpin dengan dukungan terhadap pemimpin (leader endorsement). Hasil ini sejalan dengan temuan penelitian sebelumnya, bahwa identitas agama tidak secara langsung memotivasi seseorang di dalam sebuah organisasi untuk berperilaku (Shadiqi, Muluk, \& Milla, 2018). Temuan ini kemungkinan menggambarkan bahwa identitas agama dipandang sebagai aspek kehidupan pribadi individu, sehingga pada penelitian ini, terkait dengan teori identitas sosial, persepsi terhadap identitas agama pemimpin bukanlah faktor yang memengaruhi dukungan bawahan kepada pemimpin.

Penelitian ini memiliki beberapa keterbatasan, diantaranya adalah terkait dengan isu common method bias. Penelitian ini dilakukan dengan single survey dan single source yang menurut Podsakoff, MacKenzie, dan Podsakoff (2012) lebih rawan menyebabkan common method bias. Penelitian ini juga belum menganalisis faktor-faktor yang memengaruhi leader endorsement dari sisi persepsi pemimpin. Jumlah pastisipan pada penelitian ini juga belum terlalu banyak, sehingga tidak dapat melihat efek interaksi dengan lebih akurat. Penelitian-penelitian selanjutnya diharapkan dapat menyelidiki faktorfaktor yang memengaruhi dukungan bawahan terhadap pemimpin (leader endorsement) pada lingkup organisasi yang berbeda, sehingga dapat diperoleh gambaran yang lebih lengkap terutama dalam konteks lingkungan dan iklim organisasinya. Penelitian selanjutnya juga dapat melihat proses pembentukan leader endorsement tidak sebatas proses dalam diri seseorang, dengan hanya mengandalkan evaluasi, pengakuan, atau dukungan dari orang lain, tetapi juga sesuatu yang mengevaluasi diri pemimpin (claiming and granting theory). Dengan kata lain, teori ini menjelaskan bahwa proses kepemimpinan yang baik tercipta melalui hubungan yang resiprokal, arti- 
nya dukungan bawahan terhadap pemimpin akan terjadi ketika pemimpin juga mengklaim identitas kepemimpinannya (Marchiondo, Myers, \& Kopelman, 2015).

Berdasarkan perspektif teori identitas sosial, prototypical leader akan cenderung lebih didukung oleh bawahannya (van Knippenberg \& Hogg, 2003). Namun, hasil penelitian ini mengungkapkan hal yang berbeda bahwa seorang pemimpin yang non-prototypical di sebuah organisasi akan tetap dapat memperoleh endorsement dari bawahannya, karena faktor-faktor yang memengaruhi dukungan bawahan terhadap pemimpin tidak hanya ditentukan oleh prototipikal, tetapi lebih ditentukan oleh personal power yang dimiliki pemimpin (leaders' expert power dan leaders' referent power). Temuan ini sejalan dengan hasil penelitian lain yang menggambarkan dukungan bawahan terhadap pemimpin akan tercipta juga tergantung pada kondisi-kondisi tertentu (misalnya self-uncertainty bawahan) dan konteks lingkungannya (Rast dkk., 2012). Sehingga, hasil penelitian ini dapat memberikan kontribusi terhadap perkembangan teori identitas sosial bahwa identitas sosial pemimpin pada konteks perusahaan swasta bukan menjadi faktor yang menentukan dukungan terhadap pemimpin. Selain itu, temuan penelitian ini juga dapat membantu para praktisi di perusahaan atau organisasi untuk lebih memahami bagaimana interaksi yang terjadi antara bawahan dan pemimpin dalam melihat faktor-faktor yang dapat secara efektif memengaruhi leader endosement.

\section{Kesimpulan}

Penelitian ini menunjukkan bahwa tidak ada hubungan yang signifikan antara leader prototypicality dan leader endorsement. Artinya, proses terbentuknya dukungan terhadap pemimpin tidak dapat dilihat hanya berdasarkan identitas kepemimpinan yang mencerminkan identitas organisasinya. Prototypical leader tidak selamanya lebih didukung dibandingkan non-prototypical leader. Sedangkan leaders' expert power dan leaders' referent power berpengaruh positif terhadap leader endorsement. Temuan penelitian ini menggambarkan bahwa pemimpin yang memiliki kemampuan atau keahlian pengetahuan tertentu dan juga memiliki kharisma atau keteladanan akan sangat didukung oleh bawahannya. Hasil ini juga menegaskan bahwa leaders' expert power dan leaders' referent power memang menjadi faktor yang mampu meningkatkan efektivitas dalam kepemimpinan (Biong dkk., 2010; Haslam dkk., 2013), sehingga akan memengaruhi leader endorsement.

\section{Daftar Pustaka}

Bachman, J. G., Smith, C. G., \& Slesinger, J. A. (1966). Control, performance, and satisfaction: An analysis of structural and individual effects. Journal of Personality and Social Psychology, 4(2), 127-136. doi: $10.1037 / \mathrm{h} 0023615$

Biong, H., Nygaard, A., \& Silkoset, R. (2010). The influence of retail management's? Use of social power on corporate ethical values, employee commitment, and performance. Journal of Business Ethics, 97, 341-363. doi:10.1007/s10551-010-0497-y

Chiu, C. Y. C., Balkunid, P., \& Weinberg, F. (2015). When managers become leaders: The role of manager network centralities, social power, and followers' perception of leadership. The Leadership Quarterly, 28(2), 334-348. doi:10.1016/j.leaqua.2016.05.004

Cicero, L., Pierro, A., \& Knippenberg, D. Van. (2010). Leadership and uncertainty: How role ambiguity affects the relationship between leader group prototypicality and leadership effectiveness. British Journal of Management, 21, 411-421. doi:10.1111/j.1467-8551.2009.00648.x

DeRue, D. S. D. E., \& Ashford, S. J. (2010). Who will lead and who will follow? A social process of leadership identity construction in organizations. Academy of Management Review, 35(4), 627-647. doi:152.118.24.10

Dijke, M. van, \& Cremer, D. De. (2010). Procedural fairness and endorsement of prototypical leaders: Leader benevolence or follower control? Journal of Experimental Social Psychology, 46(1), 8596. doi:10.1016/j.jesp.2009.10.004

Dutton, J. E., Roberts, L. M., \& Bednar, J. (2010). Pathways for positive identity construction at work: Four types of positive identity and the building of social resources. Academy of Management Review, 35(2), 265-293. doi:10.5465/AMR.2010.48463334

Epitropaki, O., \& Martin, R. (2004). Implicit leadership theories in applied settings: Factor structure, generalizability, and stability over Time. Journal of Apllied Psychology, 89(2), 293-310. doi:10.1037/0021-9010.89.2.293

Epitropaki, O., Sy, T., Martin, R., Tram-quon, S., \& Topakas, A. (2013). Implicit leadership and followership theories "in the wild": Taking stock of information-processing approaches to leadership and followership in organizational settings. The Leadership Quarterly, 24(6), 858-881. 
doi:10.1016/j.leaqua.2013.10.005

Ferris, G. R., Liden, R. C., Munyon, T. P., Summers, J. K., Basik, K. J., \& Buckley, M. R. (2009). Relationships at work: Toward a multidimensional conceptualization of dyadic work relationships. Journal of Management, 36(6), 1379-1403. doi:10.1177/0149206309344741

Geys, B. (2014). Better not look too nice? Employees' preferences towards (un) likeable managers. The Leadership Quarterly, 25(5), 875-884. doi:10.1016/j.leaqua.2014.02.001

Giessner, S. R., Knippenberg, D. van, \& Ginkel, W. van. (2013). Team-oriented leadership: The interactive effects of leader group prototypicality, accountability, and team identification. Journal of Applied Psychology, 98(4), 658-667. doi: $10.1037 / \mathrm{a} 0032445$

Gleibs, I. H., \& Haslam, S. A. (2016). Do we want a fighter? The influence of group status and the stability of intergroup relations on leader prototypicality and endorsement. Leadership Quarterly, 27(4), 557-573. doi:10.1016/j.leaqua.2015.12.001

Graf, M. M., Schuh, S. C., van Dick, R., \& van Quaquebeke, N. (2012). The relationship between leaders' group-oriented values and follower identification with and endorsement of leaders: The moderating role of leaders' group membership. Journal of Business Ethics, 106(3), 301-311. doi:.1007/s10551-011-0997-4

Guo, X. (2016). Leader group prototypicality and employee well-being: The mediate effect of group commitment and the moderate effect of openness. Psychology, 7(4), 591597. doi:10.4236/psych.2016.74061

Haslam, S. ., Reicher, S. ., \& Platow, M. . (2013). The new psychology of leadership: Identity, influence and power. In $P A$ : Psychology Press. doi:10.1097/PEC.0000000000001015

Haslam, S. A., \& Ryan, M. K. (2008). The road to the glass cliff: Differences in the perceived suitability of men and women for leadership positions in succeeding and failing organizations. The Leadership Quarterly, 19, 530-546. doi:10.1016/j.leaqua.2008.07.011

Hinkin, T. R., \& Schriesheim, C. A. (1989). Development and application of new scales to measure the french and raven (1959) bases of social power. Journal of Apllied Psychology, 74(4), 561-567. doi:10.1037/0021-9010.74.4.561

Hofstede, G. (2011). Dimensionalizing cultures: The hofstede model in context. Online
Readings in Psychology and Culture, 2(1), 1-26. doi:10.9707/2307-0919.1014

Hogg, M. A. (2001). A Social Identity Theory of Leadership. Personality and Social Psychology Review, 5(3), 184-200.

Ilker, E., Sulaiman, A. M., \& Rukayya, S. A. (2016). A comparison of convenience sampling and purposive sampling. American Journal of Theoretical and Applied Statistics, 5(1), 1-4. doi:10.6224/JN.61.3.105

Koivisto, S., \& Rice, R. E. (2016). Leader prototypicality moderates the relation between access to flexible work options and employee feelings of respect and leader endorsement. International Journal of Human Resource Management, 27(22), 2771-2789. doi:10.1080/09585192.2015.1126337

Mael, F., \& Ashforth, B. E. (1992). Alumni and their alma mater: A partial test of the reformulated model of organizational identification. Journal of Organizational Behavior, 13, 103-123. doi: 10.1002/job.4030130202

Marchiondo, L. A., Myers, C. G., \& Kopelman, S. (2015). The relational nature of leadership identity construction: How and when it in fl uences perceived leadership and decision-making. The Leadership Quarterly. doi:10.1016/j.leaqua.2015.06.006

Michener, H. A., \& Lawler, E. J. (1975). Endorsement of formal leaders: An integrative model. Journal of Personality and Social Psychology, 31(2), 216-223. doi:10.1037/h0076282

Oktug, Z. (2013). The moderating effects of age and tenure on the relationship between organizational identification and job satisfaction. Journal of Management, 3(4), 218-222. doi:10.5923/j.mm.20130304.04

Petrick, J. A., \& Quinn, J. F. (2000). The integrity capacity construct and moral progress in business. Journal of Business Ethics, (23), 3-18. doi:10.1023/A

Pierro, A., Cicero, L., Bonaiuto, M., van Knippenberg, D., \& Kruglanski, A. W. (2005). Leader group prototypicality and leadership effectiveness: The moderating role of need for cognitive closure. Leadership Quarterly, 16(4), 503-516. doi:10.1016/j.leaqua.2005.06.002

Platow, M. J., \& Van Knippenberg, D. (2001). A social identity analysis of leadership endorsement: The effects of leader ingroup prototypicality and distributive intergroup fairness. Personality and Social Psychology Bulletin, 27(11), 1508-1519. doi:10.1177/01461672012711011

Podsakoff, P. M., Mackenzie, S. B., \& Podsakoff, N. 
P. (2012). Sources of Method Bias in Social Science Research and Recommendations on How to Control It. Annual Review of Psychology, 63(1), 539-569. doi: 10.1146/annurev-psych-120710-100452

Rahim, M. A. (1989). Relationship of leader power to compliance and satisfaction with supervision: Evidence from a national sample of managers. Journal of Management, 15(4), 545-556. doi:10.1177/014920638901500404

Rast, D. E., Gaffney, A. M., Hogg, M. A., \& Crisp, R. J. (2012). Leadership under uncertainty: When leaders who are non-prototypical group members can gain support. Journal of Experimental Social Psychology, 48(3), 646-653. doi:10.1016/j.jesp.2011.12.013

Rast, D. E., Hogg, M. A., \& Tomory, J. J. (2015). Prototypical leaders do not always get our support: Impact of self-uncertainty and need for cognition. Self and Identity, 14(2), 135-146. doi:10.1080/15298868.2014.964755

Riyadi, N., Asakarunia, D. A., Wijaya, F., \& Riantoputra, C. D. S. (2019). The construction of positive leader identity: Acquiring a leadership position and being accepted by others. Springer, 4.

Robbins, S. P., \& Judge, T. A. (2011). Organizational Behavior (17th editi). Edinburgh Gate: Pearson Education Limited.

Shadiqi, M. A., Muluk, H., \& Milla, M. N. (2018). Palestinian solidarity action: The dynamics of politicized and religious identity patterns among student activists. Makara Hubs-Asia, 22(2), 118-128. doi:10.7454/hubs.asia.1140818
Spisak, B. R., Grabo, A. E., Arvey, R. D., \& van Vugt, M. (2014). The age of exploration and exploitation: Younger-looking leaders endorsed for change and older-looking leaders endorsed for stability. Leadership Quarterly, 25(5), 805-816. doi:10.1016/j.leaqua.2014.06.001

Ullrich, J., Christ, O., \& van Dick, R. (2009). Substitutes for procedural fairness: Prototypical leaders are endorsed whether they are fair or not. Journal of Applied Psychology, 94(1), 235-244. doi:10.1037/a0012936

van Knippenberg, D. (2011). Embodying who we are: Leader group prototypicality and leadership effectiveness. Leadership Quarterly, 22(6), 1078-1091. doi:10.1016/j.leaqua.2011.09.004

van Knippenberg, D., \& Hogg, M. A. (2003). A social identity model of leadership effectiveness in organizations. Research in Organizational Behavior, 25(3), 243-295. doi:10.1016/S0191-3085(03)25006-1

Van Vugt, M., \& De Cremer, D. (2003). Leader endorsement in social dilemmas: Comparing the instrumental and relational perspectives. European Review of Social Psychology, 13(1), 155-184. doi:10.1080/10463280240000055

Williams, E. A., Pillai, R., Deptula, B. J., Lowe, K. B., \& Mccombs, K. (2018). Personality and individual differences did charisma "Trump" narcissism in 2016? Leader narcissism, attributed charisma, value congruence and voter choice. Personality and Individual Differences, 130(March), 11-17. doi:10.1016/j.paid.2018.03.010 